\title{
PALAEOSOLS AS QUATERNARY STRATIGRAPHICAL KEY HORIZONS IN OSTROBOTHNIA, WESTERN FINLAND
}

\author{
RAIMO KUJANSUU
}

\begin{abstract}
KUJANSUU, RAIMO, 1992. Palaeosols as Quaternary stratigraphic key horizons in Ostrobothnia, western Finland. Bull. Geol. Soc. Finland 64, Part 2, 161-167.

In Ostrobothnia, western Finland, palaeosols have been recognized at several sites in the sandy deposits between glaciofluvial sediments and the overlying till. The palaeosols resemble postglacial podzol. As climatic conditions changed, the palaeosols at Kärjenkoski, Risåsen and Norinkylä were gradually covered with sand transported by the wind and rainwater, and the A horizons grew in thickness. Under early-glacial conditions the podzol was buried under proglacial sands, which, despite often being deformed by the advancing ice sheet, also contributed to the preservation of the palaeosols. According to TL and OSL dating, the palaeosols were formed 164-83 ka ago, implying that the ice-free period in southern Ostrobothnia lasted from the Saalian deglaciation to the end of the Brørup interstade or even to the beginning of the MidWeichselian. Palaeosols can be used as stratigraphic key horizons to correlate systems over large areas.

Key words: stratigraphy, Palaeosols, podzols, eskers, interglacial environment, interstadial environment, Pleistocene, Ostrobothnia, Finland.
\end{abstract}

Raimo Kujansuu: Geological Survey of Finland, SF-02150 Espoo, Finland

\section{Introduction}

Several deposits interpreted as interstadial or interglacial and including remains of podzol were found in Ostrobothnia in the 1970s in the course of the national assessment of sand and gravel resources in Finland. The till-covered esker of Risåsen at Kristiinankaupunki turned out to be of special interest (Niemelä \& Tynni 1979), and podzol-type palaeosols varying in degree of deformation have since been found in numerous places in esker cuttings. Another palaeosol, this one with a TL age of $124-156 \mathrm{ka}$, has been found in the tillcovered esker at Haapalankangas, Jurva (Niemelä \& Jungner 1991).

In summer 1970, a podzol-type palaeosol partly deformed by the continental ice was found under two till formations at Vuotso, Finnish Lapland. On the basis of the radiocarbon date it was correlated with the Peräpohjola interstadial deposits described by Korpela (1969) (Kujansuu 1972). The intensification of geological and geochemical re- search in northern Finland rapidly provided fresh insight into the glacial stratigraphy of this area, and new observations were made of interstadial and interglacial deposits; few were made of palaeosols, however.

In 1973, a fragment of podzol with partially intermixed A horizons but a clearly visible reddish brown $\mathrm{B}$ horizon, $15 \mathrm{~cm}$ thick, was discovered in a till-covered esker at Ruottisenkylä, Pudasjärvi in Peräpohjola (Forsström 1976). The podzol was later interpreted as redeposited interstadial organics, as »a horizon resembling a fairly well developed podzol soil ... beneath the till and proved to be secondary in origin and to have been formed in that position» (Forsström 1982, see also Aario \& Forsström 1979).

\section{Palaeosol observations}

In the late 1980s and early 1990s, the number of known palaeosols was augmented by others 
found in till-covered eskers in southern Ostrobothnia at Kärjenkoski, Isojoki; Harrinkangas, Kauhajoki; Norinkylä, Teuva; and Poronkangas, Jurva (Fig. 1)

\section{Kärjenkoski, Isojoki}

A small gravel pit has been excavated in a discontinuous till-covered esker in Kärjenkoski village. The esker runs approximately from north to south in the west of Isojoki municipality, and is covered by a discontinuous till blanket $0-1 \mathrm{~m}$ thick. Uppermost there is a thin littoral deposit varying in thickness. Sounding indicates that the till layer grows thicker in the east of the esker ridge.

A layer of fine sand with a podzol-type palaeosol rests on the summit of the esker over a distance of about $20 \mathrm{~m}$ (for a detailed description of stratigraphy, see Hütt et al. in press). What makes the palaeosol of Kärjenkoski so interesting is the fact that the podzol developed in a sand layer, about one metre thick, between the esker gravel proper and the till, filling a shallow depression on the top of the esker. The type and true dimensions of the depression cannot be deduced from the present cutting, but its form might be attributed to the normal unevenness of the esker surface or to a channel or kettle hole that formed during the closing stage of sedimentation. What matters is that a small depression existed at the site when the podzol profile developed.

The lower part of the sand deposit represents either the final stage of esker sedimentation or esker sand redeposited by waves and wind during the littoral stage. A podzol-type palaeosol developed on the esker and in its surroundings under conditions very similar to those prevailing at present. As the climate deteriorated, the vegetation in the vicinity of the depression could no longer prevent the ever increasing erosion caused by wind and rain, and in places even the upper surface of the podzol in the depression was slightly eroded. Sand and the remains of the podzol Ao horizon transported from the surroundings deposited rapidly in the depression, thus protecting the palae-

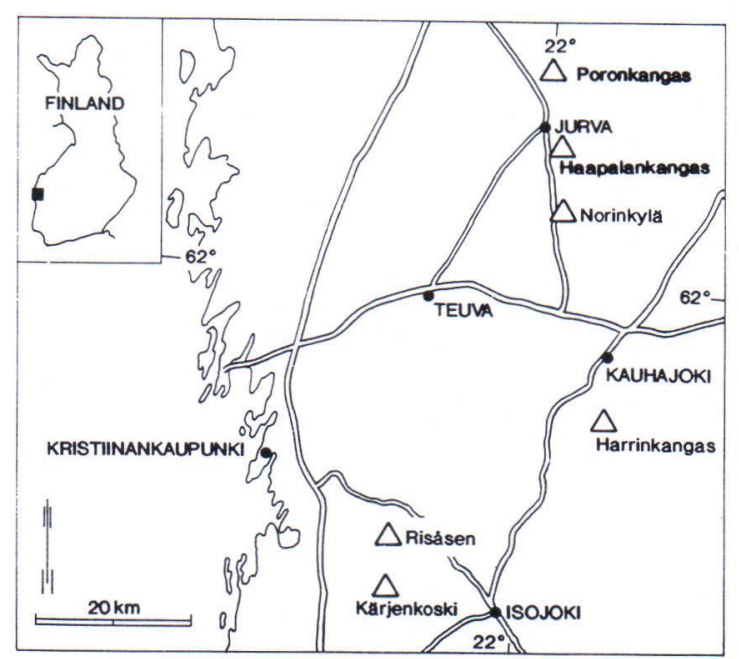

Fig. 1. The palaeosol localities in Ostrobothnia, western Finland.

osol. In the cutting this evolution is reflected in small fragments of carbon and in layers rich in fine carbon dust in the sand resting on the podzol.

As the ice sheet advanced, it deposited a till lay$\mathrm{er}$, a good $50 \mathrm{~cm}$ thick, on the formation. The sand layers underwent a slight deformation, which is now most clearly seen as small faults in the podzol profile.

\section{Risåsen, Kristiinankaupunki}

In principle the stratigraphy at Risåsen is similar to that at Kärjenkoski but, owing to the large size of the formation and the numerous cuttings in it, there are considerable variations. Here, too, the essential feature is a deposit of fine sand with a podzol in its basal part between the esker sediments proper and the till. The glaciofluvial sediment varies strikingly in texture and structure, in places exhibiting features caused by the intense glaciotectonic deformation that also deformed the podzol in the sand layer.

In the southern part of the formation there are two till units separated from each other by sorted sediments (see Niemelä \& Tynni 1979). The upper one is a till rich in the fines prevailing in the 
area. Also known as »hill clay», this till can probably be correlated to the Kauhajoki till formation described by Bouchard et al. (1990). According to fabric analyses, the lower till was deposited by an ice sheet flowing from northwest to southeast and the upper till by ice flowing approximately from north to south (Hirvas, oral comm.). Attempts to link the lower till to the local glacial history and the formation of the palaeosols have not yet fully succeeded, and there are still some gaps to be closed.

In the northern part of the Risåsen formation, on the lower slope of the esker proper and on the edge of what is presumably a rather large ancient depression, the podzol profile has been preserved almost undeformed (Fig. 2). The esker sediments are covered by a good metre of fine sand, and the podzol profile is located in their basal part (for a detailed description of stratigraphy, see Hütt et al. in press). The sand layer is covered by $70 \mathrm{~cm}$ of till, similar to that of the Kauhajoki till type. The surficial part is composed of stony gravel and sand washings formed during the littoral stage of the Holocene.

Two stages are discernible in the podzol formation, of which the lower one bears a close resemblance to that at Kärjenkoski. Characteristic of the deposit is a distinct eluvial layer and a greenish illuvial layer below the $\mathrm{A}_{0}$ horizon. At Risåsen the evolution of the podzol continued as the climate deteriorated, and sand gradually deposited, in places even as small heaps, on the podzol profile. The rate of deposition was slow enough for vegetation to take root in the sand and the $\mathrm{A}_{0}$ and $\mathrm{A}_{1}$ podzol horizons to form. Highest in the palaeosol is a distinct deformation layer, probably involution caused by cryoturbation. Under periglacial conditions, mineral matter was deposited too rapidly for podzol formation to continue. Carbon from the older podzol deposited together with sand, but to nowhere near the same extent as at Kärjenkoski, and only some dark bands are seen in the sand overlying the podzol. The early glacial stage is reflected in the formation of the upper part of the sand layer. Associated with it was a stage of weak fluvial or glaciofluvial erosion, as demonstrated by small

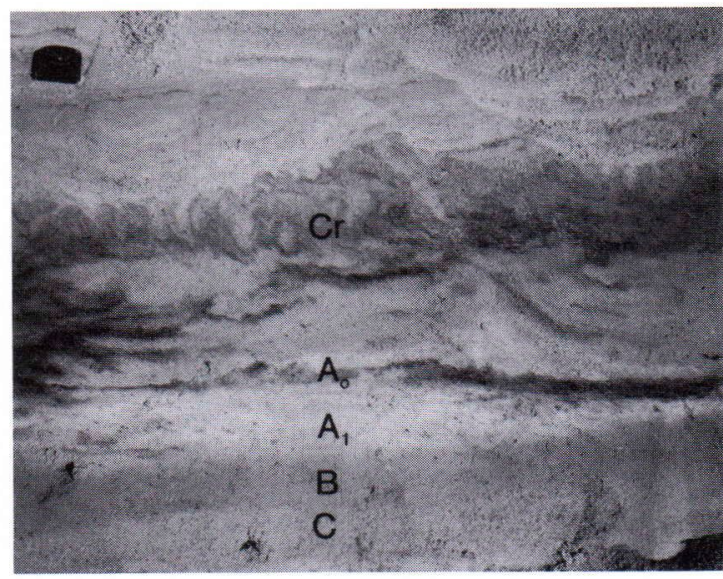

Fig. 2. A palaeosol at Risåsen, Kristiinankaupunki. The original podzol profile with $A_{0}, A_{1}$ and $B$ horizons are covered by sand containing organic matter and cryoturbation $(\mathrm{Cr})$.

channels carved into the ancient ground surface. The deposition of till caused only very slight deformation.

The deformed podzol described by Niemelä and Tynni (1979), in which the old ground surface forms a recumbent fold, is indisputable proof that the podzol profile had developed before the deformation caused by the ice sheet. The podzol profile is folded in such a way that the $\mathrm{A}_{0}$ horizons face each other, whilst the other horizons in the overlying layer face upwards and those in the underlying layer downwards (op. cit. Plate XI, cont.).

\section{Harrinkangas, Kauhajoki}

The Harrinkangas interstadial deposit has been described in detail by Gibbard et al. (1989). It fills an esker depression, probably a kettle hole, on the bottom of which less than $50 \mathrm{~cm}$ of stratified/ varved silt deposited on the esker sediment. On the silt but beneath the interstadial deposit, there is a layer of sand, about $2 \mathrm{~m}$ thick, with some boulders in its upper part and remnants of deformed podzol profile in its middle part (Hütt et al. in press). An interesting feature here, too, is the greenish hue of the remnants of the illuvial layer. 
The deformations might be attributed solely to cryoturbation under the periglacial conditions that followed podzol formation, but the position of the deposit at the bottom of a steeply sloping kettle suggests that the deformations and the occurrence of stones and boulders in the surficial part of the sand layer might be due to solifluction. There are places on the lower slopes of the depression where diamicton, possibly produced by solifluction, is mixed with organic matter beneath the interstadial deposit. What matters, however, is that all this, including the formation of podzol, took place after the esker was deposited but before the fluvial interstadial deposits described by Gibbard et al. were formed (op. cit.).

Observations of two till units separated by $3 \mathrm{~m}$ of stony gravel have been reported from the southern part of the Harrinkangas gravel extraction area. The upper till is of the Kauhajoki till formation type rich in fines, being here at its type locality (Bouchard et al. 1990). The lower one is sandy till with about $10 \mathrm{~cm}$ of silt on its surface. This may be the same silt as that underlying the palaeosol, in which case the podzol formation postdates the lower till. The lower till and the underlying esker sediment are both stained by iron oxides but the gravel between the tills appears to be »cleaner».

\section{Norinkylä, Teuva}

A till-covered esker runs from north to south through Norinkylä village. A gyttja lens found in a gravel pit excavated at the edge of the esker north of the village has been described by Niemelä \& Tynni (1979) (see also Donner 1988). In the middle of a gravel pit south of Norinkylä there is a »tower» left unscathed by extraction as the esker gravel here is covered by $5 \mathrm{~m}$ of till underlain by $4 \mathrm{~m}$ of sand (Fig. 3). In all likelihood, here, too, the podzol-type profile developed at the bottom of a kettle hole (for detailed stratigraphic description, see Hütt et al. in press).

In the deposit with the podzol the esker sediments are overlain by about $20 \mathrm{~cm}$ of stratified or varved silty clay. This is covered by about half a metre of sand that deposited in shallow water or at least during a littoral stage. It was in this sand that the podzol then developed. Characteristic of this illuvial layer, too, is the greenish hue seen in the other deposits described. Although thicker, the podzol horizons are less well developed than at Kärjenkoski, probably because of their coarse grain size. The increase in thickness of the A horizon, as if it had gradually grown upwards, is probably due to the location of the podzol at the bottom of an esker kettle. As the climate cooled the deposition of sand gradually accelerated, and the podzol was covered by $90 \mathrm{~cm}$ of deformed sand. Here, as at Risåsen, the deformation could have been caused by frost. Under early glacial conditions the kettle was filled with $4 \mathrm{~m}$ of sand, and the overriding ice sheet covered the rest of the depression with $5 \mathrm{~m}$ of till.

\section{Haapalankangas, Jurva}

The till-covered esker chain trending southwards and beginning west of the centre of Jurva is probably part of the Norinkylä esker chain. Poorly developed podzol covered by proglacial sand has been found at several spots in a gravel pit at Haapalankangas (Niemelä \& Jungner 1991). Although poorly developed and locally intensely deformed, the podzol profile is in principle in the same stratigraphic position as the above deposits.

Note that two till units with a fairly thick gravel layer between them have also been observed at Haapalankangas. In the southern gravel pit, the lower till contains abundant organics; the upper till resembles the Kauhajoki till type.

\section{Poronkangas, Jurva}

About $10 \mathrm{~km}$ north of Jurva church there is an extensive, discrete, elongated till-covered glaciofluvial formation that probably belongs to the same esker chain as the two above deposits, although the connection has not yet been verified. In the middle of the formation a podzol profile has developed in coarse-grained glaciofluvial sediments covered by a till bed, one metre thick. As no protective sand was laid down at the site the 


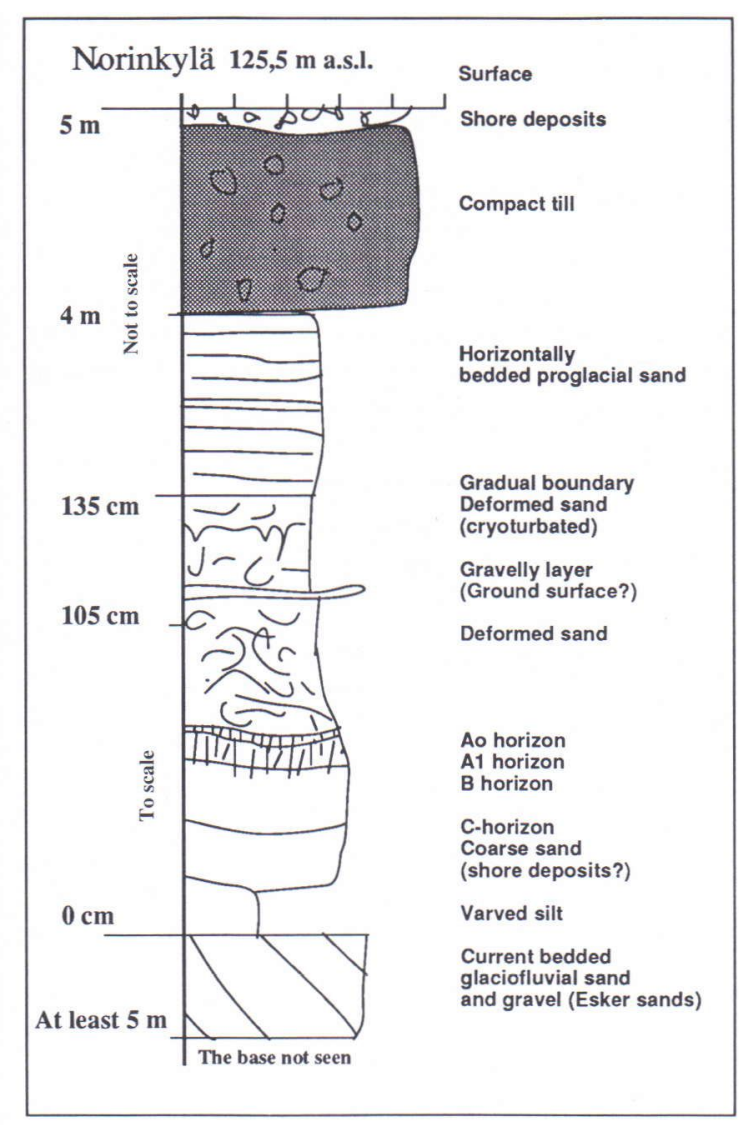

Fig. 3. Stratigraphy of the till-covered esker at Norinkylä. The glaciofluvial sands are covered by a shallow layer of silt, $4 \mathrm{~m}$ of sand and $5 \mathrm{~m}$ of till, all filling an ancient kettle hole at the bottom of which a palaeosol developed in the lower part of the sand layer.

podzol was poorly preserved, and it was eventually destroyed by gravel extraction in winter 1990 91.

\section{Age of the palaeosols}

The dating of Early Weichselian and older events has turned out to be problematic, because deposits older than $40000-50000$ years cannot be dated reliably with the radiocarbon method. The
TL and OSL methods may offer a solution. A number of carefully determined TL dates are now available from Ostrobothnia, e.g. from Kärjenkoski (Kujansuu et al. 1991), Risåsen, Norinkylä and Haapalankangas (Niemelä \& Jungner 1991), which are Late Saalian or Eemian. Experience of OSL suggests that it may enable us to differentiate between Eemian and Early Weichselian deposits (Hütt et al., in press). The OSL dates from Kärjenkoski, Risåsen and Norinkylä podzols can be grouped into two age classes: 1) Late Saalian, or 136-164 ka, and 2) Early Weichselian, or 83108 ka (op.cit.).

\section{Palaeosols in studies of Quaternary stratigraphy}

Palaeosols provide convincing evidence of the existence of ice-free conditions before the last glaciation. A complete podzol profile is easy to recognize and it is generally clearly in situ. The chemical changes that took place in the profile are similar to those that affected the postglacial podzols developed in glaciofluvial sand (Kujansuu et al. 1991). The structures of the palaeosols provide insight into the geological evolution and climatic conditions at the time the podzol was formed. The following conclusions can be drawn from the observations and dates available.

1. The eskers formed during the Saalian deglaciation were largely submerged by the Eem Sea in Ostrobothnia. Shallow littoral formations were deposited during the littoral stage. In places these are underlain by stratified or varved silts deposited in deep water. Aeolian action also deposited sand.

2. Owing to uplift, a podzol profile developed in littoral/aeolian sand deposits, partly also directly in coarse glaciofluvial sediments, during the Eemian.

3. As the climate cooled and vegetation diminished the podzol started to erode through the action of wind and rain. In suitable depressions, sand and the remains of the eroding podzol profile gradually deposited on the podzol profile, resulting in increased thickness of the Ao horizon. 
4. Cryoturbation and solifluction (gelifluction?) took place under periglacial conditions.

5. Proglacial sands, which protected the podzol from later glacial erosion, were deposited on the podzol under early-glacial conditions.

6. In southern Ostrobothnia, the continental ice sheet deposited the Kauhava till formation on the sediments, thus folding and deforming the podzol profile.

It is evident from the OSL dates that the icefree stage in southern Ostrobothnia continued from the Eemian to the end of the Brørup interstade. Whether the evolution continued uninterrupted through the Odderade interstade to the beginning of the Mid-Weichselian is not yet known. Some OSL dates suggest that the ice-free period might even have continued to the beginning of the MidWeichselian, in which case podzol formation did not come to an end until early-glacial glaciofluvial activities started. However, stratigraphic observations of two till formations separated by glaciofluvial sediments viz. at Risåsen, Harrinkangas and Haapalankangas, contradict this interpretation. Another possibility that should not be discounted is that the lower till reflects the binary nature of Saalian depositional action (cf. Salonen et al. 1992).

\section{References}

Aario, R.\& Forsström,L., 1979. Glacial stratigraphy of Koillismaa and North Kainuu, Finland. Fennia 157:2, 49 p.

Donner, J. 1988. The Eemian site of Norinkylä compared with other interglacial and interstadial sites in Ostrobothnia, Western Finland. Annales Academiae Scientiarum Fennicae A III $149,38 \mathrm{p}$.

Bouchard,M., Gibbard,P.\& Salonen, V-P., 1990. Lithostratotypes for Weichselian and pre-Weichselian sediments in southern and western Finland. Bulletin of The Geological Society of Finland 62:1, 79—95.

Forsström, L., 1976. Till-covered organic material in Pudasjärvi (in Finnish). Stratigrafia-Symposio 08. 09. 1976. Suomen Geologinen Seura, Geologiliitto r.y. Koulutusmoniste 2, 56 66. Espoo.

Forsström, L., 1982. The Oulainen Interglacial in Ostrobothnia, western Finland. Acta Universitatis Ouluensis A 136, 116 p.

Forsström, L., 1988. The northern limit of pine forest in Finland during the Weichselian interstadials. Annales Academiae
Till-covered eskers in which the sediments at the edges are underlain by a till with interglacial microfossils and overlain by deposits with interstadial microfossil have been observed in central Ostrobothnia (Iisalo 1992). Such a stratigraphy implies that the Early Weichselian deglaciation in central Ostrobothnia produced eskers that were then covered by a till containing interstadial material (cf. Forsström 1988). However, it is possible that southern Ostrobothnia was ice-free from the Saalian deglaciation to the end of the Brørup interstade, if not longer.

It can be concluded that palaeosols are probably more common than previously thought and that they occur in areas where glacial erosion was weak during the last glaciation and where interstadial and interglacial deposits are common, i.e. in Ostrobothnia, Peräpohjola and Lapland. By observing and studying them in detail we will be able to elaborate our picture of geological evolution during the problematic Early Weichselian stage and acquire new instruments to correlate the systems of large areas.

Acknowledgements. Satu Moberg draw the figure 1 and Gilian Häkli translated the text into English.

Scientiarum Fennicae A III 147, 24 p.

Gibbard, P., Forman, S., Salomaa, R., Jungner, H., Peglar, S., Suksi, J. \& Vuorinen, A., 1989. Pleistocene stratigraphy at Harrinkangas, Western Finland. Annales Academiae Scientiarum Fennicae A III 150, 36 p.

Hütt, G. Jungner, H., Kujansuu, R. \& Saarnisto, M. in press. OSLand TL-dating of buried fossil podzols and covering sands in Ostrobothnia, western Finland.

Iisalo, E., 1992. Observations on the stratigraphy of Weichselian tills and subtill eskers in Central Ostrobothnia, Finland. Geological Survey of Finland, Report of Investigation 112, 42 p.

Korpela, K., 1967. Die Weichsel-Eiszeit und ihr Interstadial in Peräpohjola (nördliches Nordfinnland) im licht von submoränen Sedimenten. Annales Academiae Scientiarum Fennicae A III 99, 108 p.

Kujansuu, R., 1972. Interstadiaalikerrostuma Vuotsossa. Summary: Interstadial deposits at Vuotso, Finnish Lapland. Geologi $24,53-56$.

Kujansuu, R., Saarnisto, M., Räisänen, M.-L.\& Hansel, A., 1991. Fossil soil of Kärjenkoski and its correlatives in Ostrobothnia, 
western Finland. In S. Autio (ed.) Geological Suvey of Finland, Current Research 1989-1990. Geological Survey of Finland, Special Paper 12, 119-126.

Niemelä, J. \& Jungner, H., 1991. Thermoluminescence dating of Late Pleistocene sediments related to till-covered eskers from Ostrobothnia, Finland. In S. Autio (ed.) Geological Survey of Finland, Current research 1989-1990. Geological Survey of Finland, Special Paper 12, 135-138.

Niemelä, J. \& Tynni, R., 1979. Interglacial and interstadial sedi- ments in the Pohjanmaa region, Finland. Geological Survey of Finland, Bulletin 302, 48 p.

Salonen, V-P., Eriksson, B. \& Grönlund, T. 1992. Pleistocene stratigraphy in from the Lappajärvi meteorite crater in Ostrobothnia, western Finland. Boreas 21, 253-269.

Received May 15, 1992

Revision accepted June 12, 1992 